\title{
A Simple Mitigation Model of Poverty Reduction in Indonesia
}

\author{
P. Eko Prasetyo1, Partono Thomas² \\ ${ }^{1}$ Department of Development Economics, Faculty of Economics, Universitas Negeri Semarang, Semarang, Indonesia \\ ${ }^{2}$ Department of Economics Education, Faculty of Economics, Universitas Negeri Semarang, Semarang, Indonesia \\ Email: pekoprasetyo@mail.unnes.ac.id,partono.thomas@mail.unnes.ac.id
}

How to cite this paper: Prasetyo, P. E., \& Thomas, P. (2021). A Simple Mitigation Model of Poverty Reduction in Indonesia. Open Journal of Business and Management, 9, 2742-2758.

https://doi.org/10.4236/ojbm.2021.96152

Received: September 30, 2021

Accepted: October 31, 2021

Published: November 3, 2021

Copyright (c) 2021 by author(s) and Scientific Research Publishing Inc. This work is licensed under the Creative Commons Attribution International License (CC BY 4.0).

http://creativecommons.org/licenses/by/4.0/ (c) (i) Open Access

\begin{abstract}
Sustainable development (SDG) aims to reduce poverty in all places, including Indonesia. The purpose of this research is to theoretically and empirically explain a simple model of mitigation and poverty reduction. This research applies a fixed-effect model and path analysis techniques using regional panel data from 35 regencies and cities in 2017-2020 in Central Java, Indonesia. Furthermore, the results showed that the Keynesian theory which states that unemployment causes poverty is valid and relevant while the statement of economic growth being the most effective aspect in poverty reduction is not entirely true. The main empirical research results confirmed that the Human Development Index (HDI) factor is the most effective aspect as a key to success and a strong foundation capital in mitigating and reducing poverty. Meanwhile, Income per Capita (IPC), government spending, GRDP, and investment are the main drivers to increase HDI and reduce poverty.
\end{abstract}

\section{Keywords}

Mitigation Model, Reduce Poverty, Human Development Index and Economic Growth

\section{Introduction}

In economic theory, increasing economic growth is a requirement to reduce unemployment and poverty. Indonesia has achieved moderately fast economic growth for most of the past 50 years (Hill, 2021). But in reality, the majority of Indonesians are still poor or what may be termed "precariously nonpoor" (Hill, 2021; OECD, 2021; World Bank, 2021b). According to Sittha (2012), the "propoor growth" policy alone without good governance performance is insufficient for enhancing poverty reduction equally in Thailand. Economic growth does not 
influence the poverty reduction in Indonesia (Afandi et al., 2017). The implication of this is that Indonesia needs to expand its social protection programs to assist the new poor in addition to the existing poor (Suryahadi et al., 2020). That is, there is still a gap between theory and empirical, so that the objectives of the four track strategy development policy are: pro growth, pro poor, pro job and pro equity in Indonesia considered a failure. Therefore, the implications and contributions of the study in our article seek to offer a new strategy model for poverty mitigation and reduction, especially in Indonesia.

Poverty, unemployment, and inequality in income distribution are the main problems of global development that need to be mitigated and overcome. During this global pandemic, poverty and unemployment increased due to the drastic economic slowdown and other socioeconomic crises (Gul et al., 2020; Parolin \& Wimer, 2020; ILO, 2021). The Indonesian government and the world have made many efforts to reduce poverty, unemployment, and inequality in income distribution (World Bank, 2021a; Buheji et al., 2021; Prasetyo, 2021). However, these efforts are not meant to mitigate, and awareness to overcome them is also often too late, thus the various efforts that have been made are expensive and in vain. The impact of the pandemic has caused per capita income to fall by more than $90 \%$ in emerging markets and developing economies (EMDE). This brings millions of people back into poverty, as was the case at the end of 2017 (World Bank, 2021a). Furthermore, the pandemic also hampers prospects for future poverty reduction and adversely affects long-term productivity, growth, investment, and the quality of education (World Bank, 2021a; Buheji et al., 2021).

According to Keynesian theory, poverty occurs unintentionally and is caused mainly by unemployment. Meanwhile, scarcity theory proposes that it causes a scarcity mindset, forcing the poor to take less than optimal decisions and behaviors (Bruijn \& Antonides 2021). According to Bruijn and Antonides (2021), poverty leads to empowerment and triggers trade-off thinking, although methodological problems prevent firm conclusions. It was concluded that theoretical and empirical work was still needed to build a more robust theory. Meanwhile, Davis and Martinez (2014) stated that each economic approach has an important contribution to understanding poverty, but no theory is sufficiently complete, hence selective synthesis is needed. Economic task eliminates important aspects of the nature and causes of poverty (Davis \& Martinez 2014).

The Keynesian theory states that economic growth is the most effective aspect of poverty reduction. However, statistically, the nature of the relationship between economic growth, poverty, and unemployment is still unclear (Haveman \& Schwabish, 2007; Muhammad \& David, 2019). Empirically, the research results of Reinstadler and Ray (2010) argued that the regional unemployment rate has a direct and indirect impact on poverty. Unfortunately, policymakers generally take it for granted that economic growth reduces poverty. The results of studies on the relationship between economic growth and poverty rates in the US reveal different trends. Meanwhile, Haveman and Schwabish (2007) found that 
since 1993, there has been a positive relationship between the unemployment rate and poverty as well as a negative relationship between the growth of Gross Domestic Product (GDP) and the poverty rate. Furthermore, the research results of Haveman and Schwabish (2007), including other researchers, found that the relationship between economic growth and poverty rates was broken during the 1980s. Meanwhile, Freeman's (2008) research showed a strong relationship between the two during the 1980s. Furthermore, the latest research and articles related to economic growth, unemployment, and poverty with regional data at the provincial level in Vietnam, showed that public investment had a positive and significant impact on economic growth and unemployment. Meanwhile, unemployment, export-import, and public investment harm economic growth and poverty (Quy, 2016).

The purpose of this research is to build a new, stronger framework for Keynesian theory by using regional empirical data on cases in Indonesia. Furthermore, this theory is used as a basic argument to find out the role of other macro variables such as government spending, investment, GRDP, and per capita income in influencing unemployment and poverty. According to Keynesian theory, fiscal policy affects aggregate demand directly through government spending and indirectly through taxation. Furthermore, this research is also based on the recommendations of previous research which concludes that theoretical and empirical work is needed to build a new and stronger theory (Bruijn \& Antonides, 2021). Therefore, these approaches are considered urgent because they have an important contribution and novelty of simple mitigation models to better understand poverty problems related to unemployment, investment, GRDP, government spending, per capita income, and especially human capital capacity as measured by Human Development Index (HDI).

This research is expected to provide basic implications for better and stronger policies to mitigate and eradicate unemployment and poverty through quality HDI in Indonesia, which is in line with the SDG goals. This novelty seeks to increase the capacity building of HDI which is increasingly qualified to create various decent and productive work opportunities as well as to promote inclusive and sustainable economic growth, without unemployment and poverty. Various literature studies refer to the many ways that poverty is conceptualized and measured because different measures of poverty tend to produce different poor people. However, the main focus of this research is to examine theoretically and empirically the condition of poverty-related to unemployment and economic growth or per capita income. The theoretical basis that is criticized and built in empirical studies uses the basic model of a Keynesian theory which states that poverty occurs because of unemployment, and economic growth is considered the solution and the most important element to reduce this problem.

Structurally, the urgency of this research is to explain the relevance of Keynesian theory on poverty alleviation with empirical data in Indonesia. Therefore, the main theory used as the basis for the study in this research is Keynes theory 
which states that economic growth is the most effective element in poverty alleviation. Novelty of this research used a simpler mitigation model with the main variable being the human capital index (HDI) in poverty alleviation. Meanwhile, other macroeconomic variables are considered as reinforcers in the model. Furthermore, the implications of this research are expected to strengthen the basis of Keynes' theory.

\section{Literature Review}

According to Classical theory, poverty is a matter of life choice and individual responsibility. However, Neo-classical theory has a broader scope that poverty occurs beyond individual control, especially in the presence of market failures. Meanwhile, Keynesian theory is more centered on the role of money in poverty and emphasizes the importance of government functions, economic stability, and public goods. Poverty occurs unintentionally and is mainly due to unemployment. This is in line with the Neo-Classical theory that overall income growth is the most effective aspect of poverty reduction. In Keynesian theory, excessive inflation, high national debt, and inflated assets are other macroeconomic factors, besides weak aggregate demand that is believed to be the main cause of poverty. Meanwhile, Marxian theory and empirical research conclude that economic growth is good for poverty reduction. Although it is not enough, because the extent to which economic growth reduces poverty depends on how it is measured, and the ability of the poor to absorb the pattern of growth (Skare \& Druzeta, 2016). This phenomenon implies that Neo-Classical and Keynesian theory still has to be critiqued and reconstructed.

The Keynesian theory also states that the capital provided, including education, plays an important role with physical and human capital as a strong foundation for achieving economic prosperity. According to Marxian theory, poverty occurs because of class and group discrimination, where those who belong to a certain class may not be able to enjoy the benefits of economic growth. Therefore, economic growth is not enough to overcome poverty, although income adequacy remains a key factor. This theory assumes that poverty is a moral and technical problem. Furthermore, Amarta Sen's theory includes aspects of justice in their institutional politics. Poverty is considered inadequate to achieve certain minimum capabilities and the lack of these abilities is absolute hence this problem is relative and absolute. Also, Amartya Sen (1983) measures poverty in terms of the "relative" poverty line, which is generally accepted as a relevant concept for the poor in many countries.

Social protection policy models such as cash transfers for poverty alleviation need to be re-evaluated (Degirmenci \& Ilkkaracan, 2013). Furthermore, Creating multiple job opportunities for women in low-income households is considered a more effective and sustainable strategy against poverty than cash (Degirmenci \& Ilkkaracan, 2013). This shows that Keynesian theory which is more centered on the role of money in poverty needs to be revised and strengthened in various as- 
pects. Alkire et al. (2021) proposed to use the ratio of the number of heads of households adjusted for the Multidimensional Poverty Index (MPI). It is the main poverty measure for policy research, which is supplemented by the ratio of heads, intensity, number of poor people, and composition of poverty to provide a more accurate analysis. The results found a strong and almost half reduction in poverty in the period 2005-2016 in India and explained that the MPI respects the monotony of dimensions (Alkire et al., 2021). Meanwhile, other recent studies demonstrated the multidimensional nature of poverty and the multi-level organization of the socio-ecological system that presents the poverty trap (Radosavljevic et al., 2021). Furthermore, Radosavljevic et al. (2021) found that crosslevel interactions provide the possibility for people to move out of poverty. Meanwhile, Morris et al. (2020) examined entrepreneurship as a solution to poverty in developed countries although the results showed that the poverty rate did not significantly change.

According to the literature study conducted by Deaton (2005), the extent to which the role of economic growth reduced global poverty has been debated for 30 years. However, empirical evidence continues to produce different conclusions. Research in China shows that there is a short-term and long-term negative relationship between unemployment and economic growth, where the relationship between them has no impact on each other (Karikari-Apau \& Abeti, 2019). Meanwhile, the latest empirical research confirms human capital as the main driver of economic growth and competitiveness of entrepreneurship and SMEs, which reduces the unemployment rate (Prasetyo, 2020b, 2021; Prasetyo \& Kistanti, 2020). However, the role of government spending is not significant, especially in financing these micro and small businesses (Prasetyo, 2020a). In contrast, the recent empirical research in Nigeria shows that unemployment and poverty have a significant impact on economic growth in both the short and long term (Anderu, 2021). The relationship between economic growth and poverty shows less convincing results, due to the indirect relationship between the variables (Purnomo \& Istiqomah, 2019).

In various literature studies, poverty alleviation has long been the core of study for researchers in the fields of economic, social, cultural, political and institutional sciences around the world. Meanwhile, many still consider economic growth and the provision of cash assistance as the solution. In fact, it is increasingly clear that empirically in various regions there is still a dramatic increase in poverty, so that various poverty alleviation policies still need to be evaluated (Abu-Ismail, 2020; Si et al., 2021). Actually, the results of literature studies have offered many solutions to reduce poverty, namely through; business, entrepreneurship and innovation (Ali \& Ali, 2016; Hussaini \& Noma, 2019; Si et al., 2021; Amofah, 2021). However, the success of this solution has proven to be still vulnerable to disturbances such as the Covid-19 pandemic, so this article proposes a new solution model that is simple and inherent in human resource capacity. The urgency and novelty in this article is how to find a new strategy or strategy mod- 
el as a solution that is simple and easy to understand well in the context; economic, business, political, social, cultural and institutional, but still more effectively able to mitigate new poverty as well as reduce unemployment, poverty and inequality that already exists.

Concerning the SDG goals, sustainable economic growth driven by human development capacity (HDI) should be maintained and developed. In Nigeria, research shows that the relationship between economic growth and HDI is negative, not significant in the short term but significant in the long term (Abraham \& Ahmed, 2011). Meanwhile, Singh (2012) proved his hypothesis with empirical data in 15 northern states in India showing that human development as measured by HDI and per capita income has a great influence on poverty reduction. In this regard, this study applies the HDI variable as the main component in the analysis model. In Indonesia, the HDI approach provides answers to empirical problems and strengthens the Keynesian theory. Hence, policy implications are more effective, efficient, and not misdirected. It is also used as a measuring aspect of the capital capacity of human resources in an effort model to represent the achievement of community welfare.

\section{Methodology}

The methodology in this research uses panel data from the Central Statistics Agency (BPS, 2021). Therefore, the dimensions of the variable measuring the ratio data scale are sourced from BPS. Meanwhile, the analysis design used multiple correlation regression experimental model with Eviews technique, and path analysis model with SPSS technique. In the initial step, the Chow test and Hausman model test were carried out on the panel data to determine which model is the best, whether the Common Effect Model (CEM), Fixed Effect Model (FEM) or Random Effect Model (REM). Meanwhile, based on these tests, it can be found and it is decided that FEM is the best model chosen. Furthermore, with the FEM form, various multiple correlation regression experimental methods were carried out to determine which model statistically, econometrically and economic theory was the best.

In the experimental analysis model, the Eviews technique was used to find the best multiple regression model. The argument is, because Eviews is more practical in finding the best model with the panel data. However, the technical weakness is that Eviews has not been able to produce standard regression coefficient values. Meanwhile, SPSS technique can produce standard standard coefficient values, but its weakness cannot be directly used for panel data. We have conducted experimental models with the Eviews technique almost hundreds of times, only to find the best model to choose from and proceed with the SPSS technique. The results of the analysis using the Eviews and SPSS techniques are exactly the same. The argument used is the SPSS technique, because the Eview technique cannot directly generate the standard regression coefficient values as required in the form of path analysis. Furthermore, with the SPSS technique, the 
value of the standard regression coefficient in question can be obtained. The technical steps for path analysis are starting from the formation of a structural equation model until the results are found as shown in the diagram and several tables below.

The HDI is a concise measure for assessing long-term progress in three basic aspects of human development namely: healthy longevity, access to knowledge, and an adequate standard of living (UNDP, 2020). Additionally, it is used as an indicator to measure the success of developing the quality of human life (BPS, 2021). In Indonesia, HDI is a strategic data because apart from being a measure of government performance, it is also used as one of the allocators for determining the General Allocation Fund (DAU). The HDI index value in this study was measured based on three aspects, namely: health, education, and spending. The approach method used is a combination of the new UNDP (2020) and BPS (2021) methods, which are measured through geometric averages as follows:

$$
\text { HDI }=\sqrt[3]{\{(\text { Health Index }) \times(\text { Education Index }) \times(\text { Expenditure Index })\} \times 100}
$$

Where life expectancy at birth (LEB), expected length of schooling (ELS), the average length of schooling (ALS), and per capita expenditure is adjusted and considered a decent standard of living. These expenditures refer to GNP per capita or income per capita (IPC). Thus, the HDI value is derived as follows:

1) Health Index $=\frac{\mathrm{LEB}-\mathrm{LEB}_{\min }}{\mathrm{LEB}_{\max }-\mathrm{LEB}_{\min }}$

2) Education Index $=\frac{I_{\mathrm{ELS}}+\mathrm{I}_{\mathrm{ALS}}}{2}$

$$
\mathrm{I}_{\mathrm{ELS}}=\frac{\mathrm{ELS}-\mathrm{ELS}_{\min }}{\mathrm{ELS}_{\max }-\mathrm{ELS}_{\min }} \text { and } \mathrm{I}_{\mathrm{ALS}}=\frac{\mathrm{ALS}-\mathrm{ALS}_{\min }}{\mathrm{ALS}_{\max }-\mathrm{ALS}_{\min }}
$$

3) Expenditure Index $=\frac{\mathrm{GNP}_{\mathrm{pC}}-\mathrm{GNP}_{\mathrm{pC} \text { min }}}{\mathrm{GNP}_{\mathrm{pC} \text {.max }}-\mathrm{GNP}_{\mathrm{pC} \text { min }}}=\frac{\mathrm{IpC}_{\mathrm{IDR}}-\mathrm{IpC}_{\mathrm{IDR} \text {.min }}}{\mathrm{IpC}_{\mathrm{IDR} \cdot \max }-\mathrm{IpC}_{\mathrm{IDR} \cdot \min }}$ or Expenditure Index $=\frac{\left[\operatorname{Ln}(\text { Expenditur })-\operatorname{Ln}\left(\text { Expenditure }_{\min }\right)\right]}{\left[\operatorname{Ln}\left(\text { Expenditure }_{\max }\right)-\operatorname{Ln}\left(\text { Expendiutre }_{\min }\right)\right]}$

The main data source is from panel data of 35 Regencies and Cities in Central Java Province, Indonesia for the period 2017-2020. This was obtained from the Central Statistics Agency (BPS, 2021), hence the method of measuring the main variables such as GRDP, government spending, capital expenditure, HDI, age, population, economic growth, income per capita, investment, unemployment, and poverty tends to follow the BPS (2021) measuring dimensions. The study design uses the experimental model method where the best model selected has passed the strict econometric and statistical test. Furthermore, the main analysis method used was multiple regression model, panel data, fixed effect model (FEM), and path analysis. In the analytical approach with the panel data regression model estimation method, there are several methods including Common Effect Model (CEM), Fixed Effect Model (FEM), and Random Effect Model (REM). However, after going through strict econometric stages, and performing statistical tests 
with the Chow test and Hausman test on the panel data regression model, it was determined that the best model to use was the FEM. Initially, the panel data multiple regression analysis methods were used with the e-Views analysis technique. However, from the e-Views technique, the output value of unstandardized regression coefficients was obtained but the regression coefficient standardized output value was not generated, thus it is easier and more efficient to use the SPSS-16 technique. Furthermore, with the help of the dummy variable technique in the FEM technique, the output standardized coefficients of standard regression are obtained as used in this analysis.

According to the results of the experimental model test, the best model as proposed can be selected by using the investment variable represented by the measurement dimension of domestic investment (PMDN), while the other variables are still the same as before. Furthermore, because the total investment variable which consists of foreign investment (PMA) and (PMDN) data is used, the model is less than optimal. Meanwhile, a structural equation system model was first compiled in the form of this method, in stages of econometric techniques to make it easier to understand path analysis derived from the panel data multiple regression analysis (FEM) model. In this case, equations number 1, 2, and 3 use the panel data multiple regression models (FEM) while equation numbers 4 and 5 are the forms of the system path analysis model. Subsequently, in terms of mathematical functions, for the basic form of the path analysis method, a simple mitigation model and poverty reduction are written and described in the following Diagram 1.

1) $\operatorname{HDI}\left(Y_{i}\right)=\alpha_{0}+\beta_{1} \operatorname{LogPDRB}\left(X_{1}\right)+\beta_{2} \operatorname{LogGE}\left(X_{2}\right)+\beta_{3} \operatorname{LogIpC}\left(X_{3}\right)+\varepsilon_{1}$

2)

$$
\operatorname{Poverty}(Z)=\alpha_{0}-\beta_{0} \operatorname{HDI}\left(Y_{i}\right)-\beta_{1} \operatorname{LogPDRB}\left(X_{1}\right)+\beta_{4} \operatorname{LogUpy}\left(X_{4}\right)
$$

$$
-\beta_{5} \log \operatorname{Inv}\left(X_{5}\right)+\varepsilon_{2}
$$

3)

$$
\operatorname{Poverty}(Z)=\alpha_{0}-\beta_{0} \operatorname{HDI}\left(Y_{i}\right)-\beta_{3} \operatorname{LogIpC}\left(X_{3}\right)+\beta_{4} \operatorname{LogUpy}\left(X_{4}\right)
$$

$$
-\beta_{5} \log \operatorname{Inv}\left(X_{5}\right)+\varepsilon_{3}
$$

4) $\operatorname{HDI}\left(Y_{i}\right)=\rho Y_{i} \cdot X_{1}+\rho Y_{i} \cdot X_{2}+\rho Y_{i} \cdot X_{3}+\varepsilon_{1}$

5) $\operatorname{Poverty}(Z)=-\rho Z \cdot X_{3}+\rho Z \cdot X_{4}-\rho Z \cdot X_{5}-\rho Z \cdot Y_{i}+\varepsilon_{2}$

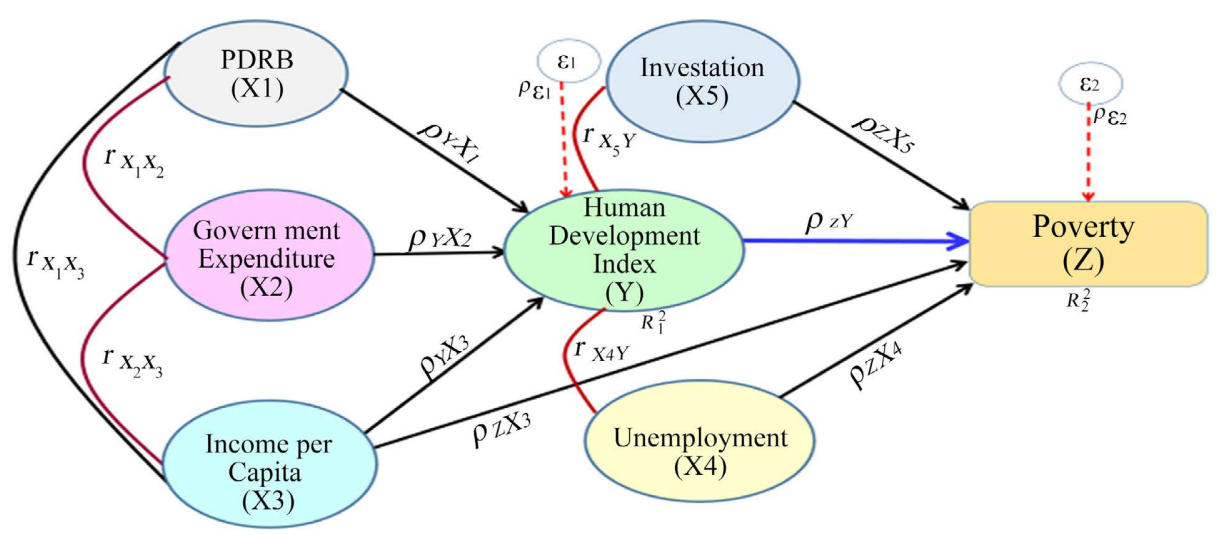

Diagram 1. Simple mitigation model and poverty reduction. 


\section{Empirical Results and Discussion}

After The objective of global development policy is to improve the welfare of the people fairly and equitably. Theoretically and empirically, the role of economic growth and Income per Capita (IPC) as the main instrument to reduce unemployment and global poverty, has been widely debated for decades until now (Deaton, 2005; Prasetyo, 2021). Neo-Classical and Keynesian economic theorists agree that overall income growth is considered the most effective aspect of poverty alleviation. However, some recent empirical research states disagree (Haveman \& Schwabish, 2007; Degirmenci \& Ilkkaracan, 2013; Skare \& Druzeta, 2016; Muhammad \& David, 2019). The Marxian theory also argues that economic growth is not enough to reduce poverty. Therefore, the agreement on the basic concepts of Neo-Classical and Keynesian theory needs to be re-evaluated. However, this study does not use the basic concepts of the Marxian theory but uses the basic concepts of other variables in Keynesian macroeconomics, especially the human development index (HDI). It also uses other physical capital, such as investment, government expenditure, and capital expenditure as a variable aspect of government roles and functions. Furthermore, two other variables are maintained, namely, GRDP rate and Income per Capita which are used as measuring dimensions of economic growth variables, while unemployment and poverty variables are used to cross-check the concept of the basic model of the theory.

According to Keynesian theory, poverty is caused by unemployment, and the solution is economic growth as the most effective aspect. However, this research does not fully support the basic concept of Keynesian theory. Table 1 model-5 shows that unemployment has a positive and significant effect of $11.8 \%$ on poverty. This means that the Keynesian theory which states unemployment as the poverty cause is valid and can still be accepted theoretically and empirically. Therefore, the results of this empirical research support the Keynesian theory that unemployment causes poverty which is still valid and relevant. However, the solution which states that economic growth is the most effective aspect empirically is not entirely true. This is because other variables contribute more effectively and are dominant than economic growth. In this research model, the economic growth variable is represented by income per capita (IPC) and the rate of GRDP. According to Table 1 model-5, it seems increasingly clear that the HDI variable, negatively and significantly, provides the most dominant contribution as mitigation as well as poverty reduction of $79.10 \%$. The second-largest contribution was provided by the role of income per capita of $34.7 \%$. This means that the higher the HDI level and the higher the per capita income level, the lower the economic poverty level will be. Meanwhile, the lowest contribution in the model was contributed by the investment variable of $6.9 \%$. This means that these results consider HDI as the most important aspect in mitigating and alleviating poverty, with economic growth acting as a complement rather than the main aspect. However, these results also do not support the previous research 
Table 1. Path analysis research results on simple mitigation models and poverty reduction.

\begin{tabular}{|c|c|c|c|c|c|c|}
\hline & \multirow{2}{*}{ Model } & \multicolumn{2}{|c|}{ Unstandardized Coefficients } & \multirow{2}{*}{$\frac{\text { Standardized Coefficients }}{\text { Beta }}$} & \multirow{2}{*}{$\mathrm{t}-\mathrm{Stc}$. } & \multirow{2}{*}{ Sig } \\
\hline & & $\mathrm{B}$ & Std. Error & & & \\
\hline \multirow{6}{*}{4} & (Constant) & -344.775 & 13.900 & & -24.804 & 0.000 \\
\hline & $\log \_$PDRB $\left(X_{1}\right)$ & 14.488 & 0.651 & 2.063 & 22.252 & 0.000 \\
\hline & $\log \_\mathrm{GE}\left(X_{2}\right)$ & 0.674 & 0.321 & 0.069 & 2.096 & 0.039 \\
\hline & Log_IpC $\left(X_{3}\right)$ & -3.990 & 0.636 & -0.450 & -6.272 & 0.000 \\
\hline & \multicolumn{2}{|c|}{ Dependent variable: HDI $\left(Y_{i}\right)$} & \multicolumn{2}{|c|}{$\mathrm{R}$ Square $=0.9985$} & \multicolumn{2}{|c|}{ Adjusted $\mathrm{R}^{2}=0.9980$} \\
\hline & \multicolumn{2}{|c|}{ Total observations $=140$} & \multicolumn{2}{|c|}{ Durbin-Watson $=1.7940$} & \multicolumn{2}{|c|}{ R Multiple $=0.9990$} \\
\hline \multirow{7}{*}{5} & (Constant) & $1.752 \mathrm{E} 6$ & $300,283.251$ & & 5.836 & 0.000 \\
\hline & Log_IpC $\left(X_{3}\right)$ & $-46,192.055$ & 19045.573 & -0.347 & -2.425 & 0.017 \\
\hline & Log_Upy $\left(X_{4}\right)$ & $11,623.443$ & 3386.811 & 0.118 & 3.432 & 0.001 \\
\hline & Log_PMDN $\left(X_{5}\right)$ & -1013.488 & 584.627 & -0.028 & -1.734 & 0.001 \\
\hline & Log_HDI $\left(Y_{i}\right)$ & $-11,860.733$ & 1638.120 & -0.791 & -7.240 & 0.000 \\
\hline & \multicolumn{2}{|c|}{ Dependent variable: Poverty $(Z)$} & \multicolumn{2}{|c|}{$\mathrm{R}$ Square $=0.9910$} & \multicolumn{2}{|c|}{ Adjusted $\mathrm{R}^{2}=0.9870$} \\
\hline & \multicolumn{2}{|c|}{ Total observation $=140$} & \multicolumn{2}{|c|}{ Durbin-Watson $=2.1380$} & \multicolumn{2}{|c|}{ R Multiple $=0.9960$} \\
\hline
\end{tabular}

Source: Panel data (FEM) \& Path Analysis Model.

which stated that HDI had a positive and significant effect on poverty rates (Yusuf \& Dai, 2020).

In the literature study, poverty often occurs due to various reasons, both from within and from outside itself, including unemployment. Therefore, the poverty nature is also economic, material, social, relative, and absolute. However, based on the research results in Table 1 , the worst causes of poverty are low productivity and laziness levels. This is due to the low talent and capacity of human capital reflected in HDI as the main model in mitigating poverty. The lower the HDI level, the easier it is for unemployment and poverty to occur and the more difficult it is to prevent and eradicate. Conversely, the higher the HDI level, the lower the unemployment and poverty rate. Furthermore, this result strengthens previous research (Prasetyo, 2021) which concluded that the "Schumpeter effect" is more dominant than the "refugee effect". This means that the growth of MSMEs and entrepreneurship is significantly better able to reduce the unemployment rate in Indonesia. However, the existence of unemployment tends to become increasingly difficult to be able to create new MSMEs and entrepreneurship. This means that those who are unemployed have high laziness levels and low productivity levels, therefore unemployment has a positive impact on poverty. Previously, Morris et al. (2020) had examined entrepreneurship as a solution to poverty in developed countries. However, the results showed that the poverty rate did not change significantly. Also, Morris (2021) has emphasized that despite the substantial obstacles faced by the poor, pursuing entrepreneurship should still be a good norm for alleviating poverty. 
According to this research, in Indonesia, critical notes on the implications of the social protection policy model such as cash transfers of aid funds (BLT) for poverty alleviation should be re-evaluated. This is because the cash transfer policy is not efficient in poverty alleviation and can make people lazy, which in turn makes poverty more complicated. Furthermore, when such a cash transfer is available, it should only be specified for groups of poor people who are elderly, including those having no relatives, and not for healthy and productive people. According to the research results in Diagram 2, it is recommended that government spending should be used to encourage the development of productive human resource capacity (HDI) including being able to mitigate and reduce poverty. Therefore, government spending, GRDP, income per capita, investment, and economic growth will be more effective and efficient to build HDI's capacity than providing cash transfer funds to unemployment and poverty. Moreover, provided the HDI capacity is getting better, the government's performance will also be better and more effective in reducing unemployment and poverty. According to Duncan et al. (2007), government policies through preschool intervention programs will be able to reduce poverty in the future. The next critical note is theoretically based on this research results, meaning that the basic concept of the Keynesian theory above, which is more centered on the role of cash in poverty, needs to be revised. Preferably, government spending is better used to strengthen production factors, especially the human capital capacity (HDI) as the basic foundation or the most important and effective aspect, including being the key to success in mitigating unemployment and new poverty. Meanwhile, policies to increase government spending, investment, and economic growth should serve as complementary factors in alleviating unemployment and poverty.

According to Diagram 2, the direct role of GRDP, government spending, and income per capita on HDI will increase the ability of the community's real productivity. Furthermore, the increase in productive capacity can prevent and at the same time reduce unemployment and poverty in the community. These

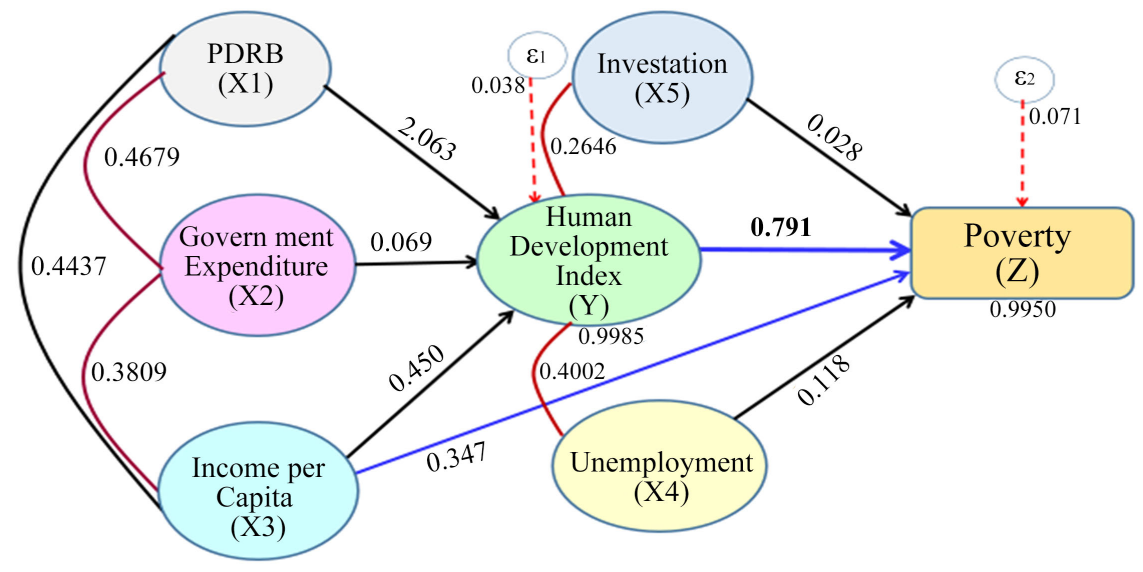

Diagram 2. A model of simple mitigation and poverty reduction. 
results support previous research which states that labor productivity has a negative and significant effect on poverty (Firman et al., 2019). Furthermore, the results of empirical research of Firman et al. (2019) explain that labor productivity has a positive and significant effect on economic growth and per capita GRDP, while economic growth and per capita GRDP do not affect poverty in West Kalimantan. This means that the research provided additional strong empirical evidence to the Keynesian theory of economic growth as the most effective aspect in poverty alleviation that was increasingly being questioned. On the other hand, the basic Keynesian theory states that the capital provided, especially education as reflected in the HDI aspect, has an increasingly vital role as a strong foundation in overcoming unemployment and poverty.

A critical note related to the role of economic growth as measured in the GRDP growth aspect, based on the results of experimental research in Diagram 3, found that the role of GRDP was still able to make a dominant and negative contribution to poverty. However, when the experimental model for the GRDP variable is replaced with the economic growth rate, the economic growth variable becomes insignificant in reducing poverty. This empirical evidence is increasingly interesting because the contribution of the HDI variable's role is still large and significant in reducing poverty. This means that the HDI factor contribution can be interpreted as the main mitigation of new unemployment and poverty. It can also be useful for reducing unemployment and poverty that has occurred more effectively and efficiently. On the other hand, the direct contribution of GRDP itself is not able to guarantee consistency in preventing and reducing unemployment and poverty.

The results of this experimental model research which was conducted before selecting and deciding the best model as shown in Diagram 2, revealed that government spending is not significant to poverty. This phenomenon indicates that the policy of providing direct cash transfers (BLT) for poverty alleviation is not successful. Therefore, it is suggested to be used in improving the quality of vital public services such as, education, health, water, sanitation, irrigation, physical infrastructure, and internet networks in rural areas that easily accessible

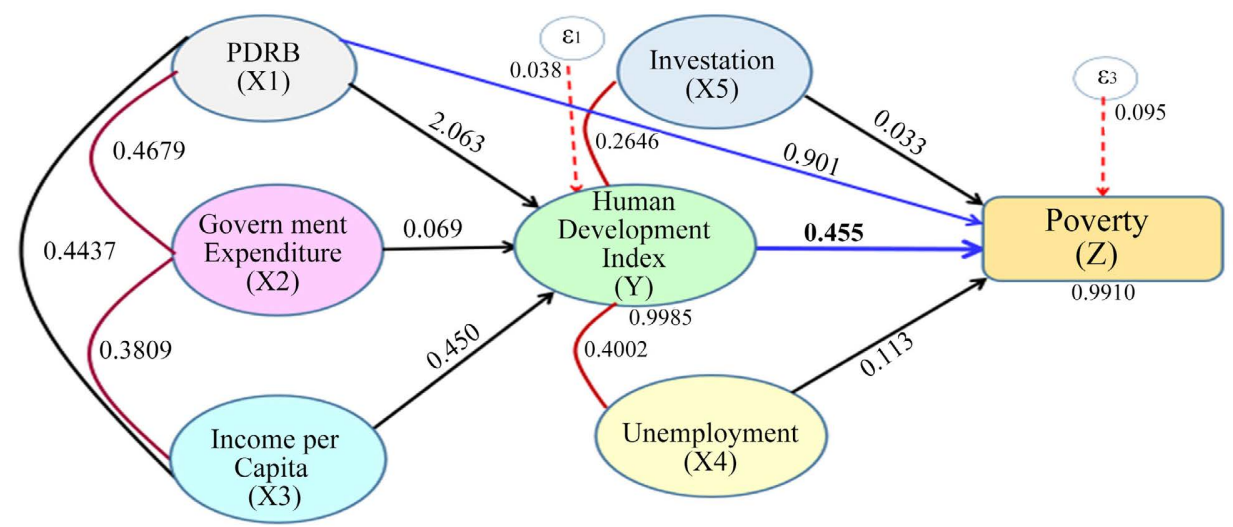

Diagram 3. Alternative models of simple mitigation and poverty reduction. 
and more productive for every poor person than cash transfers. The argument is that increasing education and health capacity is a very vital basic capital towards the success of the SDG goals. This is believed to be easily understood and accepted by all parties and empirically supported by research results using secondary data from the World Bank, which found that education and health are very important means of investing in human resources to further encourage economic growth (Widarni \& Wilantari, 2021). Therefore, the recommendations and arguments are very logical, because previous research has also found that every increase in health infrastructure spending will increase HDI, in turn, HDI and health spending will reduce poverty significantly (Ginting et al., 2019).

Provided the government policy of giving direct cash continues, it is feared that poverty will become more complex, because people are becoming more unproductive and lazy, and these cash funds are particularly prone to corruption. Furthermore, the corruption problem will make the poverty alleviation process even more complex and inefficient. The argument for providing public facilities should be executed because the poor have very limited resources with very minimal quality and high inequality including low productivity and human capital quality. Moreover, provided this problem is left unchecked, an endless cycle of poverty will continue. Therefore, through this research, the simplest solution to break the cycle of poverty is to increase the human resource capacity as reflected in the HDI aspect and increase productivity.

These results also support the research recommendations submitted by Nie and Wang (2020) and Amofah (2021) that the state should improve education to help the poor reduce the education burden of poor women's families, hence reducing the poverty rate due to sending their children to school. This recommendation is logical because poor households generally only allocate less income for basic needs such as health and education. Hence, it can be emphasized that increasing the education and health capacity of each individual from an early age is vital to mitigating new unemployment and poverty. Furthermore, the higher the level of education and public health, the higher the productivity level, which in turn will make them better able to create suitable independent productive work opportunities, and can generate money to reduce poverty. This research supports Ullah et al. (2020) that there is a positive and significant relationship between microfinance institutions (MFIs) and poverty, and recommended that MFIs should offer training sessions before giving credit because they need entrepreneurial skills, business knowledge, and mentorship. Furthermore, Rasyid et al. (2020) found that poor households allocate less of their income to basic health needs such as buying side dishes, vegetables, fruit, and meat. Rasyid et al. (2020) also recommend that any government assistance for poor households should be accompanied by education on healthy consumption patterns.

\section{Conclusion}

Poverty is the most fundamental problem in human life and development, hence 
it is difficult to eliminate. Furthermore, efforts that can be made only mitigate the emergence of new poverty and reduce its burden. Theoretically, this research results conclude that the Keynesian theory which states unemployment as the cause of poverty is still valid and acceptable. However, the role of cash and economic growth as the main element in poverty alleviation cannot be fully accepted. The main research results conclude that the role of spending on education and public health as reflected in the HDI aspect can be used as a simple mitigation model that is more effective and efficient in mitigating the occurrence of new unemployment and poverty, and at the same time to reduce the related problem. Meanwhile, other macroeconomic variables such as, investment, government spending, GRDP, and income per capita, as aspects of economic growth are not directly able to mitigate and reduce unemployment and new poverty that occurs significantly. It is recommended that the main roles and functions of various macroeconomic variables be used to promote capacity building of human resources and health including other vital public services. Therefore poor people are more productive and able to access themselves easily than proving them with cash, which is prone to corruption and can make poor people lazy and unproductive.

Thus, scientifically the results of this research are good, and statistically can be accepted and used as a good reference, and can inspire policy makers, especially Indonesia to continue to further improve the quality of human resource capabilities as reflected in the HDI value. However, this research is an empirical case study in Indonesia, so it is scientifically limited, and cannot be used to generalize to phenomena in all countries in the world. Therefore, the results of this research can be used as a basis for initial discussions and are recommended for further researchers in other countries to continue to study the same thing, so that the results of this research are more representative as a good simple model.

\section{Acknowledgements}

The authors also acknowledge the motivation and facilitator from the Faculty of Economics, Universitas Negeri Semarang, especially the committee of the professorship acceleration program, 2021. The authors declare that we have no competing interests.

\section{Conflicts of Interest}

The authors declare no conflicts of interest regarding the publication of this paper.

\section{References}

Abraham, T. W., \& Ahmed, U. A. (2011). Economic Growth and Human Development Index in Nigeria: An Error Correction Model Approach. International Journal of Administration and Development Studies, 2, 239-254.

Abu-Ismail, K. (2020). Note on Poverty and Conflict in Arab States. Un-Escwa, 6, 1-12. 
Afandi, A., Wahyuni, D., \& Sriyana, J. (2017). Policies to Eliminate Poverty Rate in Indonesia. International Journal of Economics and Financial Issues, 7, 435-441.

Ali, A. Y. S., \& Ali, A. H. (2016). Entrepreneurship Development and Poverty Reduction; Empirical Survey from Somalia. American International Journal of Social Science, 2, 108-113.

Alkire, S., Oldiges, C., \& Usha, K. (2021). Examining Multidimensional Poverty Reduction in India 2005/6-2015/16: Insights and Oversights of the Headcount Ratio. World Development, 142, Article ID: 105454. https://doi.org/10.1016/j.worlddev.2021.105454

Amofah, B. S. (2021). Indigenous Women Social Entrepreneurship; Poverty Alleviation Tool Used by Development Ngos in Ghana. Athens Journal of Social Sciences, 8, 151-168. https://doi.org/10.30958/ajss.8-2-4

Anderu, K. S. (2021). An Empirical Nexus between Poverty and Unemployment on Economic Growth. Journal of Regional Financing and Development Perspectives, 9, 85-94. https://doi.org/10.22437/ppd.v9i1.12005

BPS Badan Pusat Statistik (2021). Central Java Province in Numbers.

Bruijn, E. J., \& Antonides, G. (2021). Poverty and Economic Decision Making: A Review of Scarcity Theory. Theory and Decision, 9, 1-33.

Buheji, M., Ahmed, D., Ealmutta, W., Kuforiji, A. A., Fajana, S., Mavric, B., \& Beka, G. (2021). Depth of Global Poverty and the Economy of Lockdown. International Journal of Management (IJM), 12, 460-474.

Davis, E. P., \& Martinez, M. S. (2014). A Review of the Economic Theories of Poverty. Discussion Paper No. 435, National Institute of Economic and Social Research.

Deaton, A. S. (2005). "Measuring Poverty in a Growing World" (or "Measuring Growth in a Poor World"). Review of Economics and Statistics, 87, 1-19.

https://doi.org/10.1162/0034653053327612

Degirmenci, S., \& Ilkkaracan, I. (2013). The Impact of Household Labor Supply Structure on Poverty. Topics in Middle E Astern and African Economies, 15, 121-133.

Duncan, G. J., Ludwig, J., \& Magnuson, K. A. (2007). Reducing Poverty through Preschool Interventions. Journal of the Future of Children, 10, 143-160. https://doi.org/10.1353/foc.2007.0015

Firman, F. T., Bariyah, N., \& Kurniasih, E. P. (2019). Effect of Labor Productivity on Poverty in West Kalimantan. Journal of Development Economics, 17, 135-151. https://doi.org/10.22219/jep.v17i2.9981

Freeman, D. G. (2008). Poverty and the Macroeconomy: Estimates from U.S. Regional Data. Contemporary Economic Inquiry, 21, 358-371. https://doi.org/10.1093/cep/byg017

Ginting, R. R., Ramli, A. S., \& Zulfendri (2019). Path Analysis on Economy, Human Development Index and Poverty in Indonesia. International Journal of Civil Engineering and Technology, 10, 548-558.

Gul, A., Hussain, S., Ali, H., \& Zahra, F. (2020). COVID-19 Impact on Poverty and Unemployment Levels: A Case Pakistan. Journal of Research and Reviews in Social Sciences Pakistan, 3, 879.

Haveman, R., \& Schwabish, J. (2007). Has Macroeconomic Performance Regained Its Antipoverty Bite? Contemporary Economic Policy, 18, 415-427.

https://doi.org/10.1111/j.1465-7287.2000.tb00038.x

Hill, H. (2021). What's Happened to Poverty and Inequality in Indonesia over Half a Cen- 
tury? Asian Development Review, 38, 68-97. https://doi.org/10.1162/adev a 00158

Hussaini, U., \& Norma, L. A. (2019). Entrepreneurship as a Viable Tool for Poverty Reduction in Nigeria. International Journal of Commerce and Management Research, 5, 5-12.

ILO (2021). ILO Monitor: COVID-19 and the World of Work. Seventh Edition, Updated Estimates and Analysis. https://www.Ilo.org

Karikari-Apau, E., \& Abeti, W. (2019). The Impact of Unemployment on Economic Growth in China. MPRA Paper No. 96228. https://Mpra.Ub.Uni-Muenchen.De/96228

Morris, M. H. (2021). Poverty and Entrepreneurship in Developed Economies. In World Encyclopedia of Entrepreneurship (pp. 523-534). Edward Elgar Publishing. https://doi.org/10.4337/9781839104145.00067

Morris, M. H., Santos, S. C., \& Neumeyer, X. (2020). Entrepreneurship as a Solution to Poverty in Developed Economies. Journal Business Horizons, 63, 377-390.

https://doi.org/10.1016/j.bushor.2020.01.010

Muhammad, U. F., \& David, J. (2019). Relationship between Poverty and Unemployment in Niger State. Significant: Journal of Economics, 8, 71-78. https://doi.org/10.15408/sjie.v8i1.6725

Nie, C., \& Wang, H. (2020). A Study on the Influencing Factor of Rural Women's Poverty in Northeast China. Asian Economic and Financial, 10, 1410-1429. https://doi.org/10.18488/journal.aefr.2020.1012.1410.1429

OECD (2021). OECD Economic Surveys: Indonesia 2021. OECD Publishing.

Parolin, Z., \& Wimer, C. (2020). Forecasting Estimates of Poverty during the Covid-19 Crisis. Poverty \& Social Policy Brief, 4, 1-18.

Prasetyo, P. E. (2020a). The Role of Government Expenditure and Investment for MSMe Growth: Empirical Study in Indonesia. Journal of Asian Finance, Economics and Business, 7, 471-480. https://doi.org/10.13106/jafeb.2020.vol7.no10.471

Prasetyo, P. E. (2020b). Human Capital as the Main Determinant of Regional Economic Growth. International Journal of Advanced Science and Technology, 29, 6261-6267.

Prasetyo, P. E. (2021). The Role of MSMe on Unemployment. Turkish Journal of Computer and Mathematics Education, 12, 2519-2525.

Prasetyo, P. E., \& Kistanti, N. R. (2020). Human Capital, Institutional Economics and Entrepreneurship as a Driver for Quality \& Sustainable Economic Growth. Entrepreneurship and Sustainability Issues, 7, 2575-2589.

https://doi.org/10.9770/jesi.2020.7.4(1)

Purnomo, S. D., \& Istiqomah, I. (2019). Economic Growth and Poverty: The Mediating Effect of Employment. Journal of Economic and Policy, 12, 238-252. https://doi.org/10.15294/jejak.v12i1.18591

Quy, N. H. (2016). Relationship between Economic Growth, Unemployment and Poverty: Analysis at Provincial Level in Vietnam. International Journal of Economics and Finance, 8, 113-119. https://doi.org/10.5539/ijef.v8n12p113

Radosavljevic, S., Haider, L. J., Lade, S. J., \& Schluter, M. (2021). Implications of Poverty Traps across Levels. World Development, 144, Article ID: 105437.

https://doi.org/10.1016/j.worlddev.2021.105437

Rasyid, M., Kristina, A., Sutikno, S., \& Yuliani, T. (2020). Poverty Conditions and Pattern of Consumption: An Engel Function Analysis East Java and Bali, Indonesia. Asian Economic and Financial Review, 10, 1062-1076.

https://doi.org/10.18488/journal.aefr.2020.1010.1062.1076 
Reinstadler, A., \& Ray, J. C. (2010). Macro Determinants of Individual Income Poverty in 93 Regions of Europe. Working Paper, Population and Social Conditions; European Union.

Sen, A. (1983). Poor, Relatively Speaking. Oxford Economic Paper, 35, 153-169. https://doi.org/10.1093/oxfordjournals.oep.a041587

Si, S., Ahlstrom, D., Wei, J., \& Cullen, J. (2021). Business, Entrepreneurship and Innovation toward Poverty Reduction. Entrepreneurship \& Regional Development, 32, 1-20. https://doi.org/10.1080/08985626.2019.1640485

Singh, R. (2012). Human Development Index and Poverty Linkages. International Journal of Marketing and Technology, 2, 219-230.

Sittha, P. V. (2012). Governance and Poverty Reduction in Thailand. Modern Economy, 3, 487-497. https://doi.org/10.4236/me.2012.35064

Skare, M., \& Druzeta, R. P. (2016). Poverty and Economic Growth: A Review. Technological and Economic Development of Economy, 22, 156-175. https://doi.org/10.3846/20294913.2015.1125965

Suryahadi, A., Izzati, R. A., \& Suryadarma, D. (2020). The Impact of Covid-19 Outbreak on Poverty: An Estimation for Indonesia. The Smeru Research Institute. https://www.Smeru.or.id

Ullah, A., Pinglu, C., Yllah, S., Aslam, N., \& Zaman, M. (2020). Role of Microfinance in Poverty Alleviation in the Least Developed Area of Pakistan. Asian Economic and Financial Review, 10, 1430-1452.

https://doi.org/10.18488/journal.aefr.2020.1012.1430.1452

UNDP (2020). Human Development Report. http://hdr.undp.org/en/data

Widarni, E. L., \& Wilantari, R. N. (2021). The Relationship between Human Capital Development and Economic Growth: Evidence from Malaysia. Journal of Asian Finance, Economics and Business, 8, 641-650.

World Bank (2021a). Global Economic Prospects. World Bank. https://openknowledge.Worldbank.org/Handle/10986/34710

World Bank (2021b). Indonesia Economic Prospects: Boosting the Recovery. Washington DC. https://www.worldbank.org/id

Yusuf, L. A., \& Dai, S. I. (2020). The Impact of Unemployment and Human Development Index on Poverty in Gorontalo Province 2008-2017. Jambura Equilibrium Journal, 2, 7-16. https://doi.org/10.37479/jej.v2i1.4495 